\title{
33. $\mathrm{K} / \mathrm{Ar}$ AND ${ }^{40} \mathrm{Ar} /{ }^{39} \mathrm{Ar}$ DATING OF BASALTIC ROCKS FROM DEEP SEA DRILLING PROJECT LEG 59
}

\author{
John F. Sutter and Lawrence W. Snee, Department of Geology and Mineralogy, \\ Ohio State University, Columbus, Ohio
}

\section{INTRODUCTION}

Six basaltic whole-rock samples from DSDP Leg 59 in the Philippine Sea (Fig. 1) have been dated by a combination of $\mathrm{K} / \mathrm{Ar}$ and ${ }^{40} \mathrm{Ar} /{ }^{39} \mathrm{Ar}$ techniques. Two samples were collected from Hole 447A of the West Philippine Basin, three from Holes 448 and $448 \mathrm{~A}$ on the Palau-Kyushu Ridge (Fig. 2), and one from Hole 450 in the Parece Vela Basin. We followed a general scheme first to identify samples that are potentially closed $\mathrm{K} / \mathrm{Ar}$ systems and then to refine further the established age of these closed-system samples. Each sample of basalt that showed little or no alteration of K-bearing phases in thin section was prepared and then irradiated with fast neutrons to produce ${ }^{39} \mathrm{Ar}$ from ${ }^{39} \mathrm{~K}$ (see Dalrymple and Lanphere, 1971, 1974; and Lanphere and Dalrymple, 1971 for details of this analytical technique). After irradiation, gases (including argon) were extracted from each sample in six successively higher temperature steps, the last of which was above the melting point of the sample (called the FUSE step). The argon contained in each temperature step was purified and isotopically analyzed in order to produce six sets of argon isotopic data versus temperature for each of the samples analyzed. These data were then used to generate an age spectrum and isochron plot for each sample (see Figs. 3-5). Each rectangular box in the age spectrum plot represents the argon data for one temperature step. The width of each box is the percentage of the $\mathrm{K}$-derived ${ }^{39} \mathrm{Ar}$ released at that temperature compared to the total $\mathrm{K}$-derived ${ }^{39} \mathrm{Ar}$ released in all six temperature steps. The height of each box represents the analytical precision of the argon isotopic data released at that temperature. The analytical precision represents a standard deviation calculated at the $67 \%$ confidence level. If all temperature steps, each containing more than $5 \%$ of the total $\mathrm{K}$-derived ${ }^{39} \mathrm{Ar}$ released, have the same apparent age (using the critical value test of Dalrymple and Lanphere, 1969), then the age spectrum is said to be "concordant" (Fleck et al., 1977). The spectrum is "discordant" if these criteria are not met. The spectrum contains a "plateau" if adjacent temperature steps, each containing more than $5 \%$ of the total $\mathrm{K}$-derived ${ }^{39} \mathrm{Ar}$, are the same age (using the critical value test just cited) and together constitute more than $50 \%$ of the total K-derived ${ }^{39} \mathrm{Ar}$. The terms "disturbed spectrum" and "undisturbed spectrum" are only used when a geologic interpretation is made. For instance, an age spectrum would be termed "undisturbed" if the plateau portion defined an age that, together with other geologic information, could be interpreted as the crys-

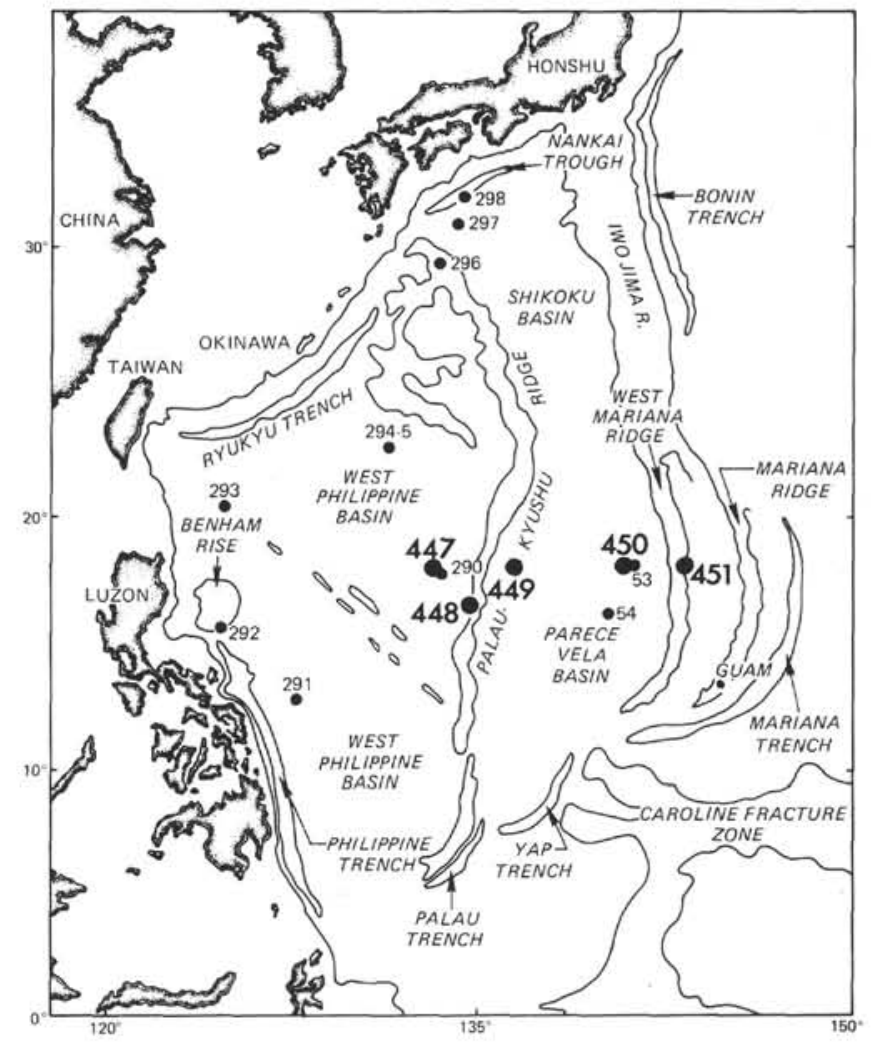

Figure 1. Site locations for DSDP Leg 59.

tallization age of the sample (hence a closed K/Ar isotopic system). An age spectrum is termed "disturbed" if, for instance, it (1) has no portion that defines a plateau, or (2) it has a plateau portion, but what it defines can be interpreted as having no geologic meaning or representing something other than the crystallization age of the sample.

Isochron plots of radiogenic plus atmospheric ${ }^{40} \mathrm{Ar}$ divided by atmospheric ${ }^{36} \mathrm{Ar}$ versus $\mathrm{K}$-derived ${ }^{39} \mathrm{Ar}$ divided by atmospheric ${ }^{36} \mathrm{Ar}$ (i.e., ${ }^{40} \mathrm{Ar}_{\mathrm{R}+\mathrm{A}}{ }^{36} \mathrm{Ar}_{\mathrm{A}}$ versus ${ }^{39} \mathrm{Ar}_{\mathrm{K}} /{ }^{36} \mathrm{Ar}_{\mathrm{A}}$ ) were prepared for most samples (e.g., Fig. $3)$. The argon isotopic data from each temperature step were plotted, and a least-squares linear regression was fitted to the data points. The slope of this line is the best fit ${ }^{40} \mathrm{Ar}_{\mathrm{R}}{ }^{39} \mathrm{Ar}_{\mathrm{K}}$ ratio for the sample, and the intercept is the initial ${ }^{40} \mathrm{Ar} /{ }^{36} \mathrm{Ar}$ ratio of the sample prior to the decay of ${ }^{40} \mathrm{~K}$ to ${ }^{40} \mathrm{Ar}$. If no loss or gain of ${ }^{40} \mathrm{Ar}$ or ${ }^{36} \mathrm{Ar}$ occurred during or after crystallization of the sample, this initial ratio should be indistinguishable from the accepted atmospheric value of ${ }^{40} \mathrm{Ar} /{ }^{36} \mathrm{Ar}-295.5$. 
${ }^{40} \mathrm{Ar} /{ }^{36} \mathrm{Ar}$ intercept values may be statistically different from the atmospheric value and/or they may show marked scatter about the regression line; such argon isochrons are indicative of a disturbed or open $\mathrm{K} / \mathrm{Ar}$ isotopic system.

Under ideal circumstances, samples that have undisturbed $\mathrm{K} / \mathrm{Ar}$ isotopic systems should have concordant ${ }^{40} \mathrm{Ar} /{ }^{39} \mathrm{Ar}$ age spectra as well as isochron plots characterized by strong colinearity of the data points that define ${ }^{40} \mathrm{Ar} /{ }^{36} \mathrm{Ar}$ intercepts as indistinguishable from the atmosphere. If these two criteria are met, the "age" of the sample can be refined by multiple conventional $\mathrm{K} / \mathrm{Ar}$ analyses.

The analytical techniques and constants used are summarized in the Appendix.

\section{ANALYTICAL RESULTS}

In the following tables and figures we present the ${ }^{40} \mathrm{Ar} /{ }^{39} \mathrm{Ar}$ and $\mathrm{K} / \mathrm{Ar}$ age data by hole.

\section{Holes 448 and 448A}

Holes 448 and 448A were drilled on the PalauKyushu Ridge (Fig. 1); the strata penetrated are diagrammatically represented in Figure 2 . Three basalt samples were selected for dating. Table 1 contains the ${ }^{40} \mathrm{Ar} /{ }^{39} \mathrm{Ar}$ data, Table 2 contains the $\mathrm{K} / \mathrm{Ar}$ data, and Figures 3 through 5 show the ${ }^{40} \mathrm{Ar} /{ }^{39} \mathrm{Ar}$ age spectra and isochrons. The uppermost sample $(448-61-3,78-85 \mathrm{~cm})$ is a plagioclase-clinopyroxene-orthopyroxene-pigeonitephyric basalt flow from Unit 13. It is our opinion that the age data from this sample from Hole 448 indicate severe loss of ${ }^{40} \mathrm{Ar}$ and that the isochron line is actually a mixing line between potassium sites that have suffered various amounts of ${ }^{40} \mathrm{Ar}$ loss. Hence we feel that no geologic meaning can be attached to the age of this sample. Samples lower in the section (448A-62-1, 70-83 cm and $448 \mathrm{~A}-64-3,2-12 \mathrm{~cm}$ ) are a plagioclase-clinopyroxene-orthopyroxene-phyric basaltic dike and an aphyric dike, respectively. The age data from these two samples satisfy all the criteria for a reliable $\mathrm{K} / \mathrm{Ar}$ system. We feel that with the data available, the "best age estimate" for each sample is an average of the ${ }^{40} \mathrm{Ar} /{ }^{39} \mathrm{Ar}$ age spectrum and the conventional K/Ar data. Thus the "best age estimate" for the sample from Core 62 is $31.45 \pm$ $1.52 \mathrm{~m} . \mathrm{y}$. and that for the sample from Core 64 is 34.88 $\pm 1.60 \mathrm{~m} . \mathrm{y}$. It is our interpretation that these ages are probably close to the crystallization age for these rock units.

\section{Hole 447A}

This hole was drilled in the West Philippine Basin. Figure 6 is a generalized diagram of the rock column recovered from Hole 447A showing the positions of two rocks analyzed by the argon techniques. The ${ }^{40} \mathrm{Ar} /{ }^{39} \mathrm{Ar}$ data are listed in Table 3 and shown graphically in Figure 7. Unfortunately, none of the samples selected for dating meet the criteria for a closed $\mathrm{K} / \mathrm{Ar}$ system, and it is our interpretation that none of the data have geologic meaning.

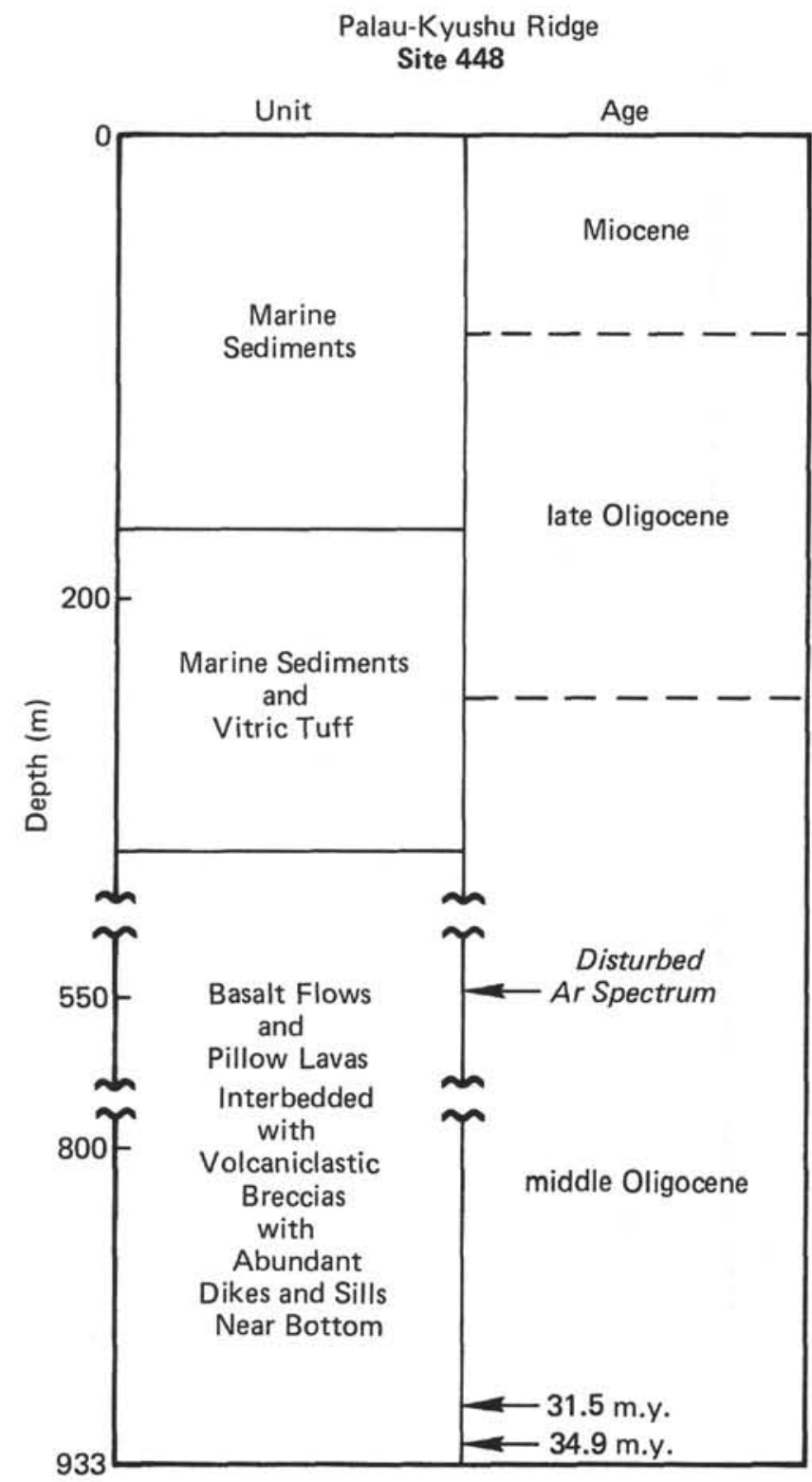

Figure 2. Highly generalized diagrammatic stratigraphic section of Holes 448 and $448 \mathrm{~A}$ showing position of dated samples (see arrows in age columm). (Notice that between 200 and $400 \mathrm{~m}$ sub-bottom and 400 and $800 \mathrm{~m}$ sub-bottom the columm is broken to save space. The uppermost sample from Core 61 of Hole 448 is at 550.3 $\mathrm{m}$ sub-bottom and the lower two are from Cores 62 and 64 of Hole $448 \mathrm{~A}$ at $887.8 \mathrm{~m}$ sub-bottom and $903.1 \mathrm{~m}$ sub-bottom, respectively.)

\section{Hole 450}

This hole was drilled in the Parece Vela Basin (Fig. 1). One sample was selected for dating; the ${ }^{40} \mathrm{Ar} / 39 \mathrm{Ar}$ data are listed in Table 4. The stratigraphic position of the sample is shown in Figure 8. The age spectrum is plotted in Figure 9, and the conventional $\mathrm{K} / \mathrm{Ar}$ data listed in Table 5. The data from this sample do not meet the criteria for a closed $\mathrm{K} / \mathrm{Ar}$ system; thus no meaning can be attached to the age data. This is dramatically 
Table 1. ${ }^{40} \mathrm{Ar} /{ }^{39} \mathrm{Ar}$ data for samples from Holes 448 and $448 \mathrm{~A}$ on the Palau-Kyushu Ridge.

\begin{tabular}{|c|c|c|c|c|c|c|c|c|}
\hline $\begin{array}{c}\text { Temperature } \\
\left({ }^{\circ} \mathrm{C}\right)\end{array}$ & $\begin{array}{l}{ }^{40} \mathrm{Ar} /{ }^{39} \mathrm{Ar} \\
\text { (measured) }\end{array}$ & $\begin{array}{c}{ }^{37} \mathrm{Ar} /{ }^{39} \mathrm{Ar} \\
\text { (measured and } \\
\text { corrected) }\end{array}$ & $\begin{array}{l}{ }^{36} \mathrm{Ar} /{ }^{39} \mathrm{Ar} \\
\text { (measured) }\end{array}$ & $\mathrm{F}$ & $\begin{array}{l}{ }^{39} \mathrm{Ar}_{\mathrm{K}} \\
\text { (\% of } \\
\text { total) }\end{array}$ & $\begin{array}{c}{ }^{40} \mathrm{Ar}_{\mathrm{R}} \\
(\%)\end{array}$ & $\begin{array}{c}{ }^{36} \mathrm{Ar} \mathrm{Ca} \\
(\%)\end{array}$ & $\begin{array}{l}\text { Age } \\
(\mathrm{m} . \mathrm{y} .)\end{array}$ \\
\hline \multicolumn{6}{|c|}{$448-61-3,78-85 \mathrm{~cm}$ (WR basalt) } & \multicolumn{3}{|c|}{$\mathrm{J}=0.006030$} \\
\hline 400 & 8.519 & 0.517 & 0.02040 & 2.528 & 20.12 & 29.66 & 0.69 & $27.29 \pm 1.81$ \\
\hline 525 & 4.027 & 1.564 & 0.007047 & 1.960 & 19.58 & 48.62 & 5.74 & $21.19 \pm 1.47$ \\
\hline 650 & 3.608 & 2.640 & 0.006540 & 1.885 & 17.31 & 52.15 & 10.98 & $20.39 \pm 1.31$ \\
\hline 800 & 4.152 & 3.685 & 0.008556 & 1.918 & 17.80 & 46.10 & 11.71 & $20.75 \pm 1.43$ \\
\hline 1050 & 2.861 & 6.790 & 0.005870 & 1.674 & 21.34 & 58.24 & 31.46 & $18.11 \pm 1.17$ \\
\hline Fuse & 4.214 & 22.82 & 0.01498 & 1.638 & 3.85 & 38.50 & 41.42 & $17.73 \pm 5.75$ \\
\hline Total Gas & & & & & & & & 21.41 \\
\hline \multicolumn{6}{|c|}{$448 \mathrm{~A}-62-1,70-83 \mathrm{~cm}$ (WR basalt) } & \multicolumn{3}{|c|}{$J=0.006645$} \\
\hline 400 & 35.68 & 4.261 & 0.1135 & 2.528 & 5.65 & 7.06 & 1.11 & $30.05 \pm 20.70$ \\
\hline 550 & 5.726 & 7.226 & 0.01255 & 2.605 & 25.73 & 45.30 & 15.67 & $30.96 \pm 2.72$ \\
\hline 650 & 4.338 & 14.57 & 0.009131 & 2.831 & 26.41 & 64.67 & 43.41 & $33.62 \pm 1.99$ \\
\hline 800 & 4.599 & 22.27 & 0.01302 & 2.573 & 13.08 & 55.16 & 46.54 & $30.59 \pm 5.49$ \\
\hline 1050 & 10.79 & 43.62 & 0.03713 & 3.413 & 17.08 & 30.76 & 31.96 & $40.46 \pm 6.60$ \\
\hline Fuse & 26.58 & 141.8 & 0.1094 & 6.207 & 2.06 & 21.26 & 35.24 & $72.92 \pm 45.78$ \\
\hline Total Gas & & & & & & & & 34.24 \\
\hline \multicolumn{6}{|c|}{$448 \mathrm{~A}-64-3,2-12 \mathrm{~cm}$ (WR basalt) } & \multicolumn{3}{|c|}{$\mathrm{J}=0.006645$} \\
\hline 400 & 53.21 & 3.232 & 0.1709 & 2.969 & 9.32 & 5.57 & 0.51 & $35.24 \pm 16.56$ \\
\hline 525 & 9.977 & 3.340 & 0.02528 & 2.774 & 29.48 & 27.75 & 3.59 & $32.95 \pm 3.69$ \\
\hline 650 & 7.310 & 7.845 & 0.01726 & 2.849 & 29.81 & 38.78 & 12.37 & $33.84 \pm 3.11$ \\
\hline 800 & 15.68 & 13.00 & 0.04829 & 2.474 & 12.52 & 15.65 & 7.32 & $29.42 \pm 7.02$ \\
\hline 1050 & 10.02 & 12.74 & 0.02755 & 2.921 & 10.22 & 28.92 & 12.58 & $34.68 \pm 5.92$ \\
\hline Fuse & 15.34 & 60.36 & 0.05549 & 3.939 & 8.64 & 24.7 & 29.58 & $46.61 \pm 9.87$ \\
\hline Total Gas & & & & & & & & 34.31 \\
\hline
\end{tabular}

Note: $\mathrm{WR}=$ whole rock; $\mathrm{K}=$ potassium; $\mathrm{R}=$ radiogenic; $\mathrm{Ca}=$ calcium; and $\mathrm{F}={ }^{40} \mathrm{Ar}_{\mathrm{R}}{ }^{39} \mathrm{Ar}_{\mathrm{K}}, \mathrm{J}=\left(\mathrm{e}^{\lambda t_{m}}-\right.$ 1) $/ \mathrm{F}$, where $t_{\mathrm{m}}=$ age of the monitor.

Table 2. K/Ar data for samples from Hole 448A on the Palau-Kyushu Ridge.

\begin{tabular}{|c|c|c|c|c|c|c|}
\hline $\begin{array}{c}\text { Satnple } \\
\text { (interval in } \mathrm{cm} \text { ) }\end{array}$ & Mineral & $\%$ & & $\begin{array}{l}\text { Moles }{ }^{40} \mathrm{ArR} \\
\text { per gram } \\
\times 10^{-11}\end{array}$ & $\frac{{ }^{40} \mathrm{Ar}_{\mathrm{R}}}{40 \mathrm{Ar}_{\text {total }}} \times 100$ & $\begin{array}{l}\text { Age } \\
\text { (m.y.) }\end{array}$ \\
\hline $448 \mathrm{~A}-62-1,70-83$ & WR & $\begin{array}{l}0.1958 \\
0.1964\end{array}$ & 0.1961 & 1.049 & 36.0 & $30.60 \pm 0.86$ \\
\hline $448 \mathrm{~A}-64-3,2-12$ & WR & $\begin{array}{l}0.2515 \\
0.2511\end{array}$ & 0.2513 & 1.600 & 20.9 & $36.36 \pm 0.58$ \\
\hline
\end{tabular}

Note: $\mathrm{WR}=$ whole rock.

demonstrated by the data in Table 5, which represent two size (mesh) fractions of the same sample. The apparent ages are grossly different and do not agree at all with the ${ }^{40} \mathrm{Ar} /{ }^{39} \mathrm{Ar}$ ages; in short, this sample has a badly disturbed $\mathrm{K} / \mathrm{Ar}$ system and is unsuitable for $\mathrm{ab}$ solute dating by the $\mathrm{K} / \mathrm{Ar}$ and ${ }^{40} \mathrm{Ar} /{ }^{39} \mathrm{Ar}$ techniques.

\section{REFERENCES}

Dalrymple, G. B., and Lanphere, M. A., 1969. Potassium-Argon Dating: Principles, Techniques, and Applications to Geochronology: San Francisco (Freeman), p. 120.

1971. ${ }^{40} \mathrm{Ar} /{ }^{39} \mathrm{Ar}$ technique to $\mathrm{K}$-Ar dating: a comparison with the conventional technique. Earth Planet. Sci. Lett., 12:300-308.

, $1974 .{ }^{40} \mathrm{Ar} /{ }^{39} \mathrm{Ar}$ age spectra of some undisturbed terrestrial samples. Geochim. Cosmochim. Acta, 38:715-738.

Fleck, R. J., Sutter, J. F., and Elliot, D. H., 1977. Interpretation of discordant ${ }^{40} \mathrm{Ar} /{ }^{39} \mathrm{Ar}$ age spectra of Mesozoic tholeiites from Antarctica. Geochim. Cosmochim. Acta, 41:15-32.

Lanphere, M. A., and Dalrymple, G. B., 1971. A test of the ${ }^{40} \mathrm{Ar} /{ }^{39} \mathrm{Ar}$ age and spectrum technique on some terrestrial materials. Earth Planet. Sci. Lett., 12:359-372.
Sutter, J. F., and Smith, T. E., 1979. ${ }^{40} \mathrm{Ar} /{ }^{39} \mathrm{Ar}$ ages of diabase intrusions from Newark Trend basins in Connecticut and Maryland: initiation of Central Atlantic rifting. Am. J. Sci., 279:808-831.

\section{APPENDIX}

\section{Analytical Techniques and Constants Used}

Techniques used are those given in Sutter and Smith (1979). Constants used in both $\mathrm{K} / \mathrm{Ar}$ and ${ }^{40} \mathrm{Ar} /{ }^{39} \mathrm{Ar}$ calculations are as follows:

${ }^{40} \mathrm{Ar} /{ }^{39} \mathrm{Ar}$ Monitor (DY-8C-71, Biotite)

$\% \mathrm{~K}^{+}=8.113 \pm 0.050$ ( 23 determinations $)$

${ }^{40} \mathrm{Ar}_{\mathrm{R}}=1.407 \pm 0.027 \times 10^{-8}$ moles $/ \mathrm{g}$ ( 6 determinations $)$

Neutron irradiation Ca-derived argon corrections (from $\mathrm{CaF}_{2}$ ):

$$
\begin{aligned}
& \left({ }^{36} \mathrm{Ar} /{ }^{37} \mathrm{Ar}\right)_{\mathrm{Ca}}=2.81 \times 10^{-4} \\
& \left({ }^{39} \mathrm{Ar} /{ }^{37} \mathrm{Ar}\right)_{\mathrm{Ca}}=7.24 \times 10^{-4}
\end{aligned}
$$

Neutron irradiation K-derived argon corrections $\left(\mathrm{K}_{2} \mathrm{SO}_{4}\right)$ :

$$
\left({ }^{40} \mathrm{Ar} /{ }^{39} \mathrm{Ar}\right)_{\mathrm{K}}=0.0059
$$

Age constants (K/ $\mathrm{Ar}$ and $\left.{ }^{40} \mathrm{Ar} /{ }^{39} \mathrm{Ar}\right)$ :

$$
\begin{aligned}
\lambda_{\beta} & =4.962 \times 10^{-10} / \mathrm{yr} \\
\lambda_{\epsilon} & =0.581 \times 10^{-10} / \mathrm{yr} \\
{ }^{40} \mathrm{~K} / \mathrm{K}_{\text {total }} & =1.167 \times 10^{-4} \text { atom } / \text { atom }
\end{aligned}
$$

Analytical uncertainties have been estimated using the procedures described by Dalrymple and Lanphere $(1971,1974)$. 

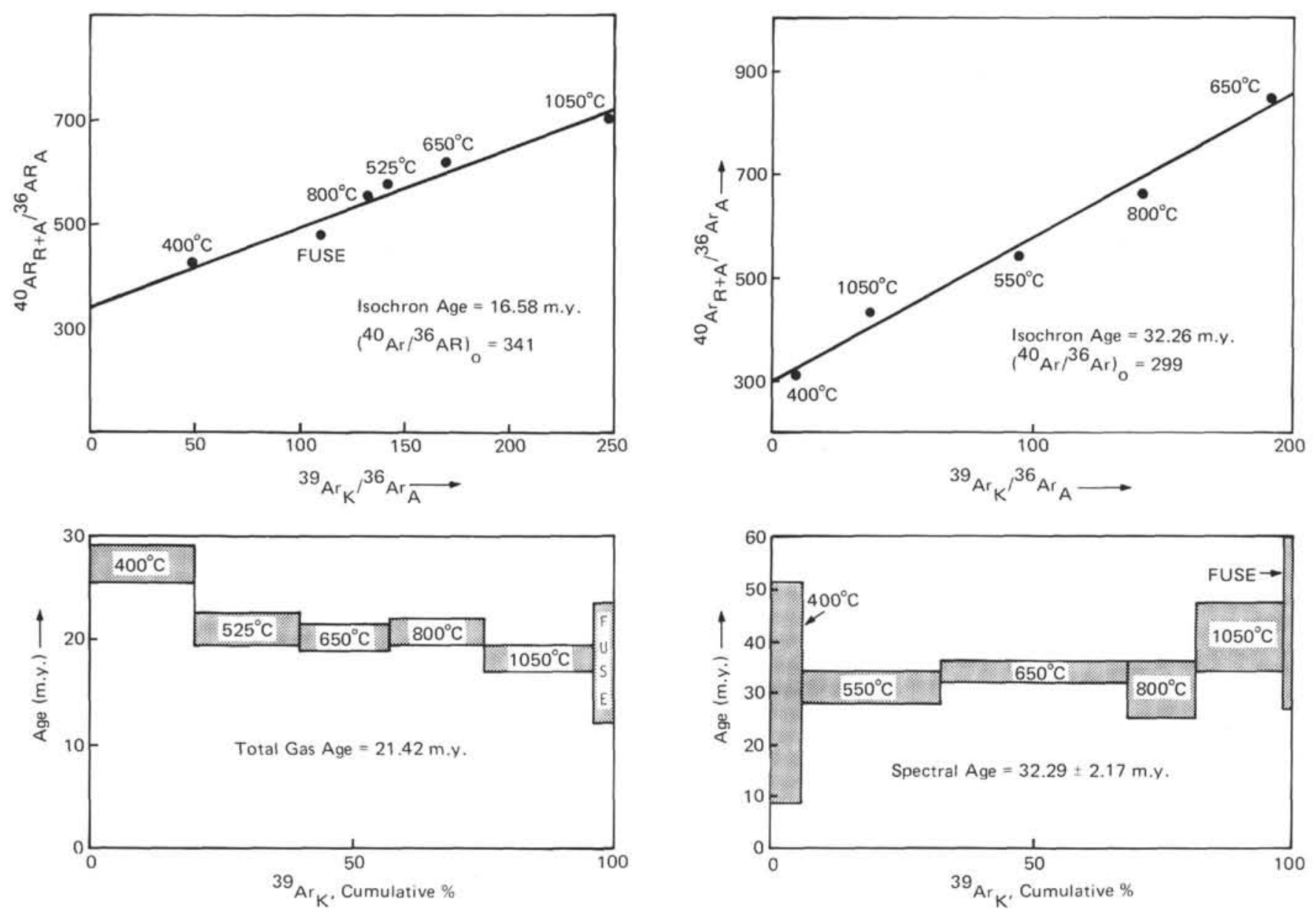

Figure $3 .{ }^{40} \mathrm{Ar} /{ }^{39} \mathrm{Ar}$ isochron diagram and age spectrum of Sample $448-61-3,78-85 \mathrm{~cm}$.

Figure $4 .{ }^{40} \mathrm{AR} /{ }^{39} \mathrm{AR}$ isochron diagram and age spectrum of Sample $448 \mathrm{~A}-62-1,70-83 \mathrm{~cm}$. 

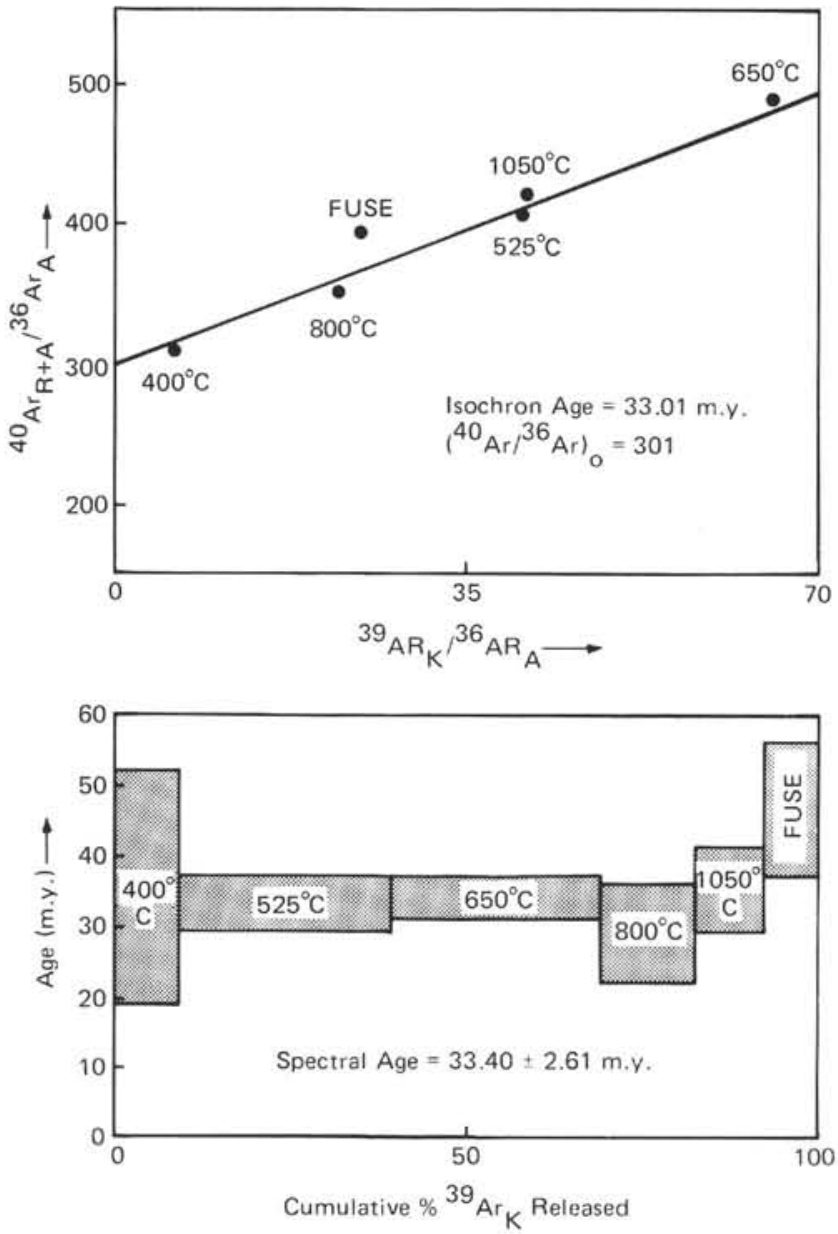

Figure 5. ${ }^{40} \mathrm{Ar} /{ }^{39} \mathrm{Ar}$ isochron diagram and age spectrum of Sample $448 \mathrm{~A}-64-3,2-12 \mathrm{~cm}$.

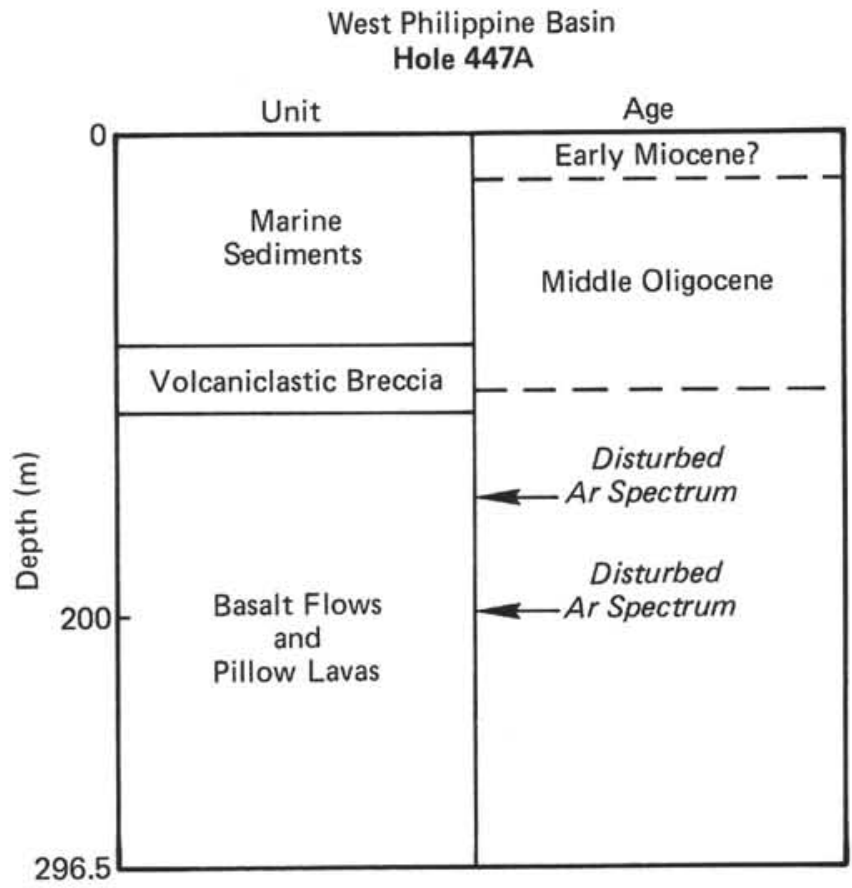

Figure 6. Diagrammatic stratigraphic section of Hole 447A showing position of dated sample (by arrow).

Table 3. ${ }^{40} \mathrm{Ar} /{ }^{39} \mathrm{Ar}$ data for samples from Hole $447 \mathrm{~A}$ drilled in the West Philippine Basin.

\begin{tabular}{|c|c|c|c|c|c|c|c|c|}
\hline $\begin{array}{c}\text { Temperature } \\
\left({ }^{\circ} \mathrm{C}\right)\end{array}$ & $\begin{array}{l}{ }^{40} \mathrm{Ar} / 39 \\
\text { (measured) }\end{array}$ & $\begin{array}{c}{ }^{37} \mathrm{Ar} /{ }^{39} \mathrm{Ar} \\
\text { (measured and } \\
\text { corrected) }\end{array}$ & $\begin{array}{l}{ }^{36} \mathrm{Ar} /{ }^{39} \mathrm{Ar} \\
\text { (measured) }\end{array}$ & $\mathrm{F}$ & $\begin{array}{l}{ }^{39} \mathrm{Ar}_{\mathrm{K}} \\
(\% \text { of } \\
\text { total) }\end{array}$ & $\begin{array}{l}{ }^{40} \mathrm{Ar}_{\mathrm{R}} \\
(\%)\end{array}$ & $\begin{array}{c}{ }^{36} \mathrm{Ar}_{\mathrm{Ca}} \\
(\%)\end{array}$ & $\begin{array}{l}\text { Age } \\
\text { (m.y.) }\end{array}$ \\
\hline \multicolumn{6}{|c|}{ Sample 447A-17-3, 144-148 cm (WR basalt) } & \multicolumn{3}{|c|}{$\mathrm{J}=0.006030$} \\
\hline 400 & 15.80 & 1.245 & 0.03434 & 5.754 & 16.95 & 36.38 & 0.99 & $61.54 \pm 6.63$ \\
\hline 525 & 10.53 & 5.426 & 0.02496 & 3.595 & 27.79 & 34.03 & 5.91 & $38.69 \pm 4.10$ \\
\hline 650 & 4.121 & 22.19 & 0.01736 & 0.782 & 8.91 & 18.71 & 34.78 & $8.48 \pm 11.13$ \\
\hline 800 & 4.199 & 28.91 & 0.01628 & 1.738 & 12.66 & 40.65 & 48.31 & $18.81 \pm 6.25$ \\
\hline 1050 & 4.350 & 35.14 & 0.01827 & 1.809 & 24.42 & 40.67 & 52.31 & $19.57 \pm 3.55$ \\
\hline Fuse & 6.533 & 84.26 & 0.03939 & 1.752 & 9.27 & 25.39 & 58.18 & $18.95 \pm 7.68$ \\
\hline Total Gas & & & & & & & & 31.10 \\
\hline \multicolumn{6}{|c|}{$447 \mathrm{~A}-25-1,28-33 \mathrm{~cm}$ (WR basalt) } & \multicolumn{3}{|c|}{$\mathrm{J}=0.006570$} \\
\hline 400 & 583.3 & 28.02 & 1.957 & 7.465 & 12.01 & 1.26 & 0.39 & $86.38 \pm 101.4$ \\
\hline 525 & 321.0 & 72.30 & 1.055 & 15.93 & 7.20 & 4.73 & 1.86 & $179.6 \pm 118.3$ \\
\hline 650 & 243.4 & 115.9 & 0.8353 & 6.282 & 11.67 & 2.39 & 3.77 & $72.96 \pm 105.7$ \\
\hline 800 & 197.8 & 133.4 & 0.6838 & 7.018 & 18.27 & 3.25 & 5.31 & $81.32 \pm 86.41$ \\
\hline 1050 & 97.59 & 198.8 & 0.3627 & 7.313 & 37.82 & 6.55 & 14.92 & $84.66 \pm 34.79$ \\
\hline Fuse & 64.80 & 576.0 & 0.3387 & 17.40 & 13.03 & 17.06 & 46.30 & $195.3 \pm 62.76$ \\
\hline Total Gas & & & & & & & & 101.2 \\
\hline
\end{tabular}

Note: See Table 1 for explanation of abbreviations. 
Table 4. ${ }^{40} \mathrm{Ar} /{ }^{39} \mathrm{Ar}$ data for samples from Hole 450 drilled in the Parece Vela Basin.

\begin{tabular}{|c|c|c|c|c|c|c|c|c|}
\hline $\begin{array}{c}\text { Temperature } \\
\left({ }^{\circ} \mathrm{C}\right)\end{array}$ & $\begin{array}{l}{ }^{40} \mathrm{Ar} /{ }^{39} \mathrm{Ar} \\
\text { (measured) }\end{array}$ & $\begin{array}{c}{ }^{37} \mathrm{Ar} /{ }^{39} \mathrm{Ar} \\
\text { (measured and } \\
\text { corrected) }\end{array}$ & $\begin{array}{l}{ }^{36} \mathrm{Ar} /{ }^{39} \mathrm{Ar} \\
\text { (measured) }\end{array}$ & F & $\begin{array}{l}{ }^{39} \mathrm{ArK}_{\mathrm{K}} \\
(\% \text { of } \\
\text { total) }\end{array}$ & $\begin{array}{c}{ }^{40} \mathrm{Ar}_{\mathrm{R}} \\
(\%)\end{array}$ & $\begin{array}{c}{ }^{36} \mathrm{Ar} \mathrm{Ca} \\
(\%)\end{array}$ & $\begin{array}{c}\text { Age } \\
\text { (m.y.) }\end{array}$ \\
\hline \multicolumn{6}{|c|}{$450-36-3,117-126 \mathrm{~cm}$ (WR basalt) } & \multicolumn{3}{|c|}{$\mathrm{J}=0.006570$} \\
\hline 400 & 9.408 & 1.452 & 0.026904 & 1.571 & 38.42 & 16.68 & 1.47 & $18.52 \pm 2.99$ \\
\hline 525 & 12.875 & 8.001 & 0.042816 & 0.865 & 19.43 & 6.68 & 5.08 & $10.22 \pm 6.20$ \\
\hline 650 & 12.928 & 22.766 & 0.047325 & 0.779 & 13.35 & 5.94 & 13.08 & $9.21 \pm 6.83$ \\
\hline 800 & 14.120 & 30.678 & 0.050002 & 1.840 & 7.90 & 12.78 & 16.69 & $21.68 \pm 10.66$ \\
\hline 1050 & 11.163 & 30.904 & 0.041262 & 1.477 & 9.17 & 12.98 & 20.37 & $17.42 \pm 8.77$ \\
\hline Fuse & 5.778 & 71.732 & 0.038407 & 0.197 & 11.74 & 3.26 & 50.80 & $2.34 \pm 8.18$ \\
\hline Total Gas & & & & & & & & 13.98 \\
\hline
\end{tabular}

Note: See Table 1 for an explanation of the abbreviations.

Table 5. $\mathrm{K} / \mathrm{Ar}$ data for sample from Hole 450 in the Parece Vela Basin.

\begin{tabular}{lccccc}
\hline $\begin{array}{c}\text { Sample } \\
\text { (interval in } \mathrm{cm} \text { ) } \\
\text { [size fraction] }\end{array}$ & Mineral & $\begin{array}{c}\mathrm{K} \\
(\%)\end{array}$ & $\begin{array}{c}\text { Moles }{ }^{40} \mathrm{Ar}_{\mathrm{R}} \\
\text { per gram } \\
\times 10^{-12}\end{array}$ & $\frac{{ }^{40} \mathrm{Ar}_{\mathrm{R}}}{400_{\mathrm{Ar}_{\text {total }}}} \times 100$ & $\begin{array}{c}\text { Age } \\
\text { (m.y.) }\end{array}$ \\
\hline $\begin{array}{l}450-36-3,117-126 \\
{[\$ 13,80 \text { to } 60 \text { mesh] }}\end{array}$ & WR & 0.4040 & 6.3863 & 11.4 & $9.09 \pm 0.20$ \\
$\begin{array}{l}450-36-3,117-126 \\
{[\# 12,30 \text { to } 48 \text { mesh] }}\end{array}$ & WR & 0.3316 & 4.2225 & 14.0 & $7.33 \pm 0.84$ \\
\hline
\end{tabular}
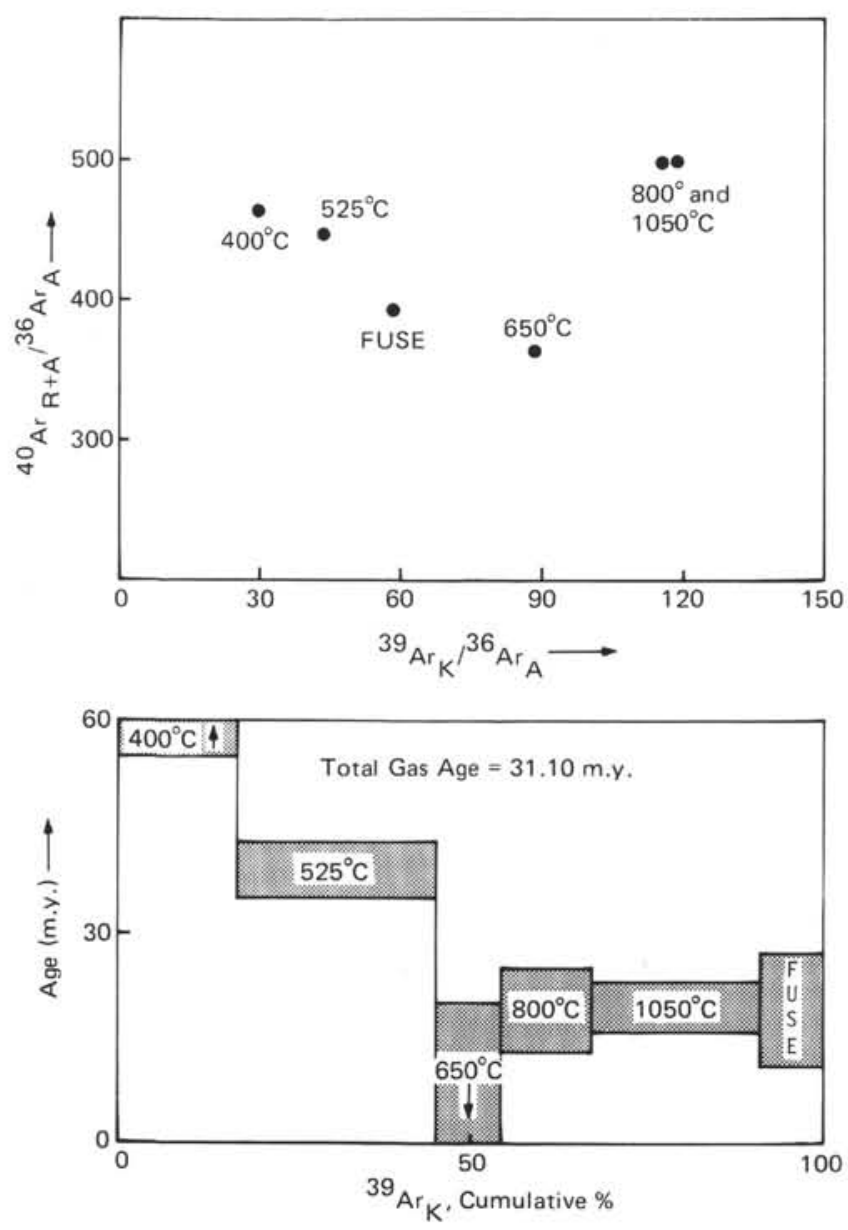

Figure 7. ${ }^{40} \mathrm{Ar} /{ }^{39} \mathrm{Ar}$ isochron diagram and age spectrum of Sample $447 \mathrm{~A}-17-3,144-148 \mathrm{~cm}$.

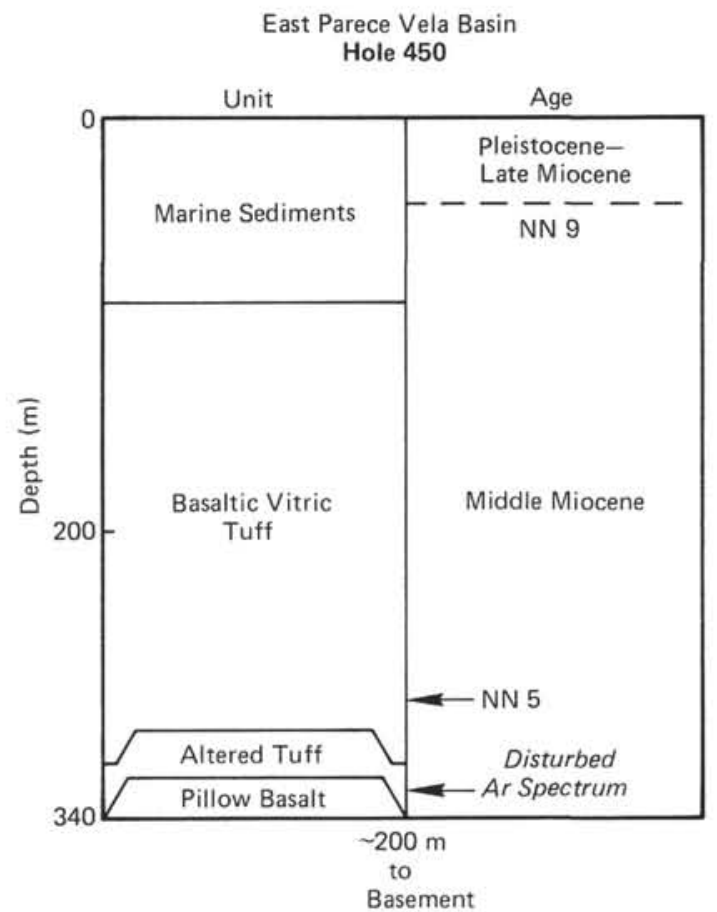

Figure 8. Diagrammatic stratigraphic section of Hole 450 showing position of dated sample (by arrows).

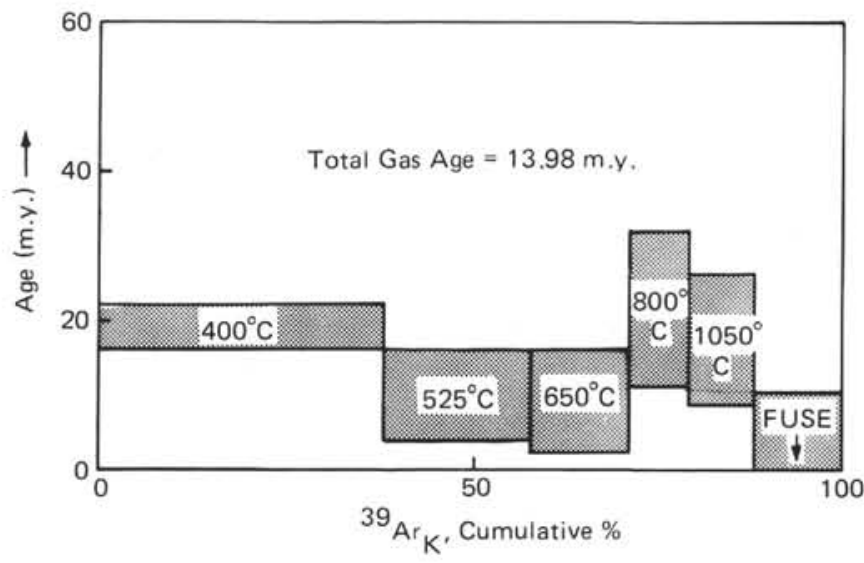

Figure $9 .{ }^{40} \mathrm{Ar} /{ }^{39} \mathrm{Ar}$ age spectrum for Sample 450-36-3, $117-126 \mathrm{~cm}$. 